\title{
Mobile science museums and centres and their history in the public communication of science
}

\section{Jessica Norberto Rocha and Martha Marandino}

Abstract

Keywords

Introduction
In this paper, we identify some milestones in the construction process for mobile science museums and centres in Brazil. As background for presenting the Brazilian context, we initially address the records found on the earliest travelling museum exhibitions and mobile museums in Europe and North America. We then introduce the role of UNESCO in the promotion and implementation of travelling science exhibitions and museums in several countries. Finally, we document important events in the history of mobile science museum and centres in Brazil and outline three general and inter-related challenges currently faced by them.

History of public communication of science; Popularization of science and technology, Science centres and museums

There is no consensus in the literature regarding the definition of a mobile science museum or centre in the field of science communication, nor in the field of museology. Supplee [1974, p. 27] made an accurate distinction between a mobile museum and travelling exhibition: the first is "a unit [...] that is equipped to carry on the activities of a museum within or around the unit itself"; the second is portable but installed in an exhibition hall.

Throughout history, however, several names have emerged to characterise the mobile movement in these fields, defined according to the characteristics that stood out at the time: "circulating exhibition", "travelling exhibition", "travelling museum", "mobile museum", "museum bus", "museum on wheels", "mobile science laboratories", "mobile science projects" and "science communication on wheels". Some programmes have also assumed generic names as "outreach" or "extension" [Zucker, 1983]. The different terms used reveal not only the diversity of initiatives, but also their conceptions, and there is often an overlap between the idea of "travelling" and "mobile" in the consulted literature. In the present study, we focus mainly on "mobile science museums and centres" - known as science communication programmes - whose principal infrastructure consists of vehicles such as trailers, trucks, buses, minibuses and vans being used for transportation of exhibits, activities and/or as exhibition venues.

Despite the multiplicity of names, the principle that unites these mobile projects, regardless of their subject area - arts, science and technology, history, natural 
history, etc. - is that of promoting access to knowledge. This, among other reasons, leads us to believe that institutions "on wheels", dedicated to the popularisation of science, are actors worthy of discussion in the history of the public communication of science and technology.

In this paper, we identify some milestones in the construction process for mobile science museums and centres in Brazil, based on research of primary and secondary sources. As background for presenting the Brazilian context, we initially address the records found on the earliest travelling museum exhibitions and mobile museums in Europe and North America. We then introduce the role of UNESCO (United Nations Educational, Scientific and Cultural Organisation) in the promotion and implementation of travelling science exhibitions and museums in several countries. Finally, we document important events in the history of mobile science museum and centres in Brazil and outline three general and inter-related challenges currently faced by them.

This descriptive and qualitative study was based on the analysis of documents originating from the field of museology, communication and education in science and technology, which provided support for the identification and characterisation of events, contexts and the trajectory of both exhibitions and mobile museums, focusing on those with scientific and technological themes, both in Brazil and internationally. We use as primary sources technical and governmental reports, minutes of meetings and conferences, manuals and publications of UNESCO and some museological institutions, public information campaigns, documents and projects from the Brazilian government and both state and non-state institutions, journalistic materials, interviews and papers by people directly involved in the field. As secondary sources, we analyse articles, dissertations, theses, research reports and documentaries.

Records of the earliest travelling exhibitions and mobile museums initiatives
At the end of the 19th century institutions started formally touring and lending their exhibitions, with the mission of spreading knowledge outside their walls. Research carried out in the USA by Zucker [1983] points out that of 390 museums surveyed in the country, 19 had outreach programs before 1900. In Europe, the Circulation Department of the Victoria and Albert Museum (UK) was created in 1850 and is considered by Floud [1950] and Morley [1950] as one of the oldest museum departments formally devoted to travelling exhibitions.

In the first half of the twentieth century, there were many agencies which specialized in providing circulating exhibitions in the USA, such as the American Federation of Arts and the Museum of Modern Art. In England, the Arts Council and the British Council, which received government support, carried out a similar service and in Canada, such services were being provided from the early 1920s. In addition, many museums in several countries (including Australia, Brazil, France, Israel, Mexico, Pakistan, Poland and Sweden) had prepared exhibitions for national or regional circulation [Museums and Monuments V. Manual of Travelling Exhibitions; Osborn and Morley, 1963].

Some institutions dedicated to scientific issues have also invested in the creation of travelling exhibitions and the loan of collections. In the United States, the American Museum of Natural History has circulated free-of-charge, since 1903, its natural 
history objects, books and manuals to schools [AMNH, 1927; Daifuku, 1963] and the Cranbrook Institute of Science organised two major travelling exhibitions in the 1940s: "The Races of Man" and "Stories in Hair and Fur" [Hatt, 1950]. Likewise, the Tekniska Museum (Sweden) and the Palais de la Découverte (France) used temporary exhibitions, which later toured nationally and internationally [Morley, 1950]. These exhibitions, however, circulated without necessarily being exhibited in a vehicle and were, therefore, entitled "circulating" or "travelling".

In the surveys we conducted, we found that Saint Louis Educational Museum was one of the earliest science exhibitions dedicated entirely to mobility, operating from a vehicle. The museum, called the "school museum" or "portable museum", had a horse and wagon to deliver its scientific collections and loan its objects, and served schools, teachers and children [Saettler, 1968; Reiser, 2001]. Its collections were composed of natural and industrial products, historical and ethnographic material, scientific instruments and apparatus and a pedagogical library. The museum's services formally began in 1905, when the teacher in charge made the museum's first journey [Zucker, 1989].

In this way, travelling and circulation in museology since the end of the 19th century influenced the creation of mobile museums, which is a phenomenon that began in the first years of the twentieth century and became more common from the 1950s. This emergence was possible because of changes to conceptions in museology and by some technological advances - which facilitated loan procedures, the circulation of collections from museums and improvements to vehicles as a result of the development of the car industry [Morley, 1950].

Another reason for their expansion was the need to include the population affected by the Second World War and to expand the educational and scientific development of various countries. In the view of Michalowski [1950], Morley [1950] and Alexander [1979], mobile exhibitions gained momentum after the war, due to the perception of their important social function, as they contributed to the spread of culture and art through all sections of the population, and in every part the country. A moral uneasiness with the population and their education was perceptible in the post-war period, and manifested itself as an obligation for museums to work on cultural extension, to make cultural values more accessible to all people. The UNESCO manual noted that:

\footnotetext{
Since the war there has been an increased awareness of the necessity and the moral obligation to extend educational opportunities and to make cultural values more readily accessible to all, without regard to social distinction or geographic isolation [Museums and Monuments V. Manual of Travelling Exhibitions, p. 12].
}

Up to this point in time, however, museums had been using the vehicles only for transportation of their exhibitions, but the exhibitions were not yet built inside the vehicles themselves. With the increasing use of travelling exhibitions and the consequent difficulties of finding suitable exhibition venues [Christison, 1955; Hudson, 1966], the vehicles were perceived not only as tools for the transportation of the collections, but were also themselves transformed into exhibition halls, culminating in the creation of so-called "mobile museums". 


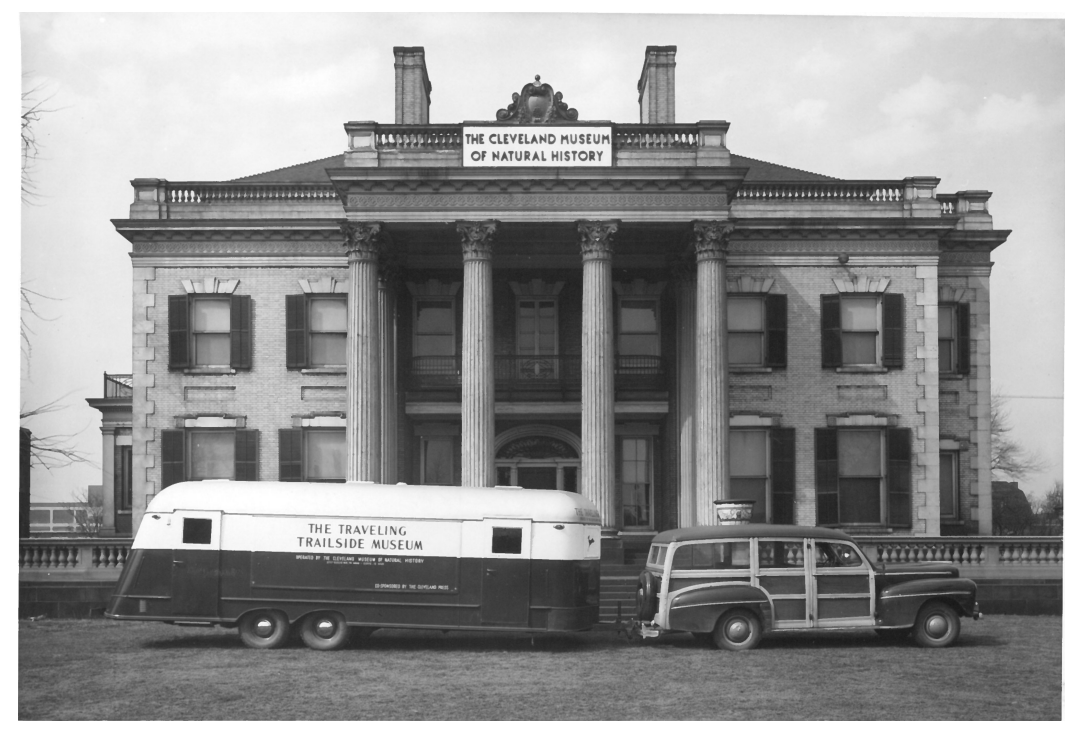

Figure 1. The Traveling Trailside Museum in front of the Cleveland Museum of Natural History, Cleveland, United States. Photograph taken by R. Marvin Wilson for the Cleveland Museum of Natural History. From the Archives of the Cleveland Museum of Natural History.

In our study, we found that the first trailer coach adapted to a museum on wheels with its interior transformed into an exhibition hall was inaugurated in Cleveland (US), in September 1947; the Traveling Trailside Museum of the Cleveland Museum of Natural History [Disher, 1947; Disher, 1950] (see Figures 1 and 2).

The Trailer, because of its limited size, controls to a certain extent the number of people who can utilize it at one time. However, due to the unique arrangement whereby one side of the Trailer lifts, it is possible to exhibit small habitat groups from the Museum's extensive collection; and by augmenting these with four upright folding panel units, it becomes possible for Traveling Trailside Naturalist to conduct outdoor lectures to larger group outside the Trailer. An introduction to the materials inside the Trailer can thus be given before entering [Disher, 1947, p. 3].

In 1948, in the same country, the mobile unit of the Illinois State Museum of Fine Arts was launched [Bose, 1983; Alexander, 1979]. The following year, Poland, which already had a strong travelling exhibition programme [Chalowski, 1950], created its first Mobile Museum from the National Museum in Warsaw [Lorentz, 2009]. In 1953, the first Artmobile of the Virginia Museum of Fine Arts was inaugurated on the American continent. Ten years later, they created another truck, the Artmobile II, and in the following years two more mobile units [Christison, 1955; Hudson, 1966].

Also in the 1950s, several other mobile units (of various themes) installed in trailers, vans, buses and trucks were inaugurated in the USA. The data presented by Grobman [1958], shows that by that time, there were, in addition to those already cited: The Mobile Exhibits of the Florida State Museum, the Mobile Unit of the Nevada State Museum, the Trailercoach of the Children's Museum of Washington, DC, the American Museum of Atomic Energy of Oak Ridge, Tennesse, and the Historymobile of the Wisconsin Historical Society. 


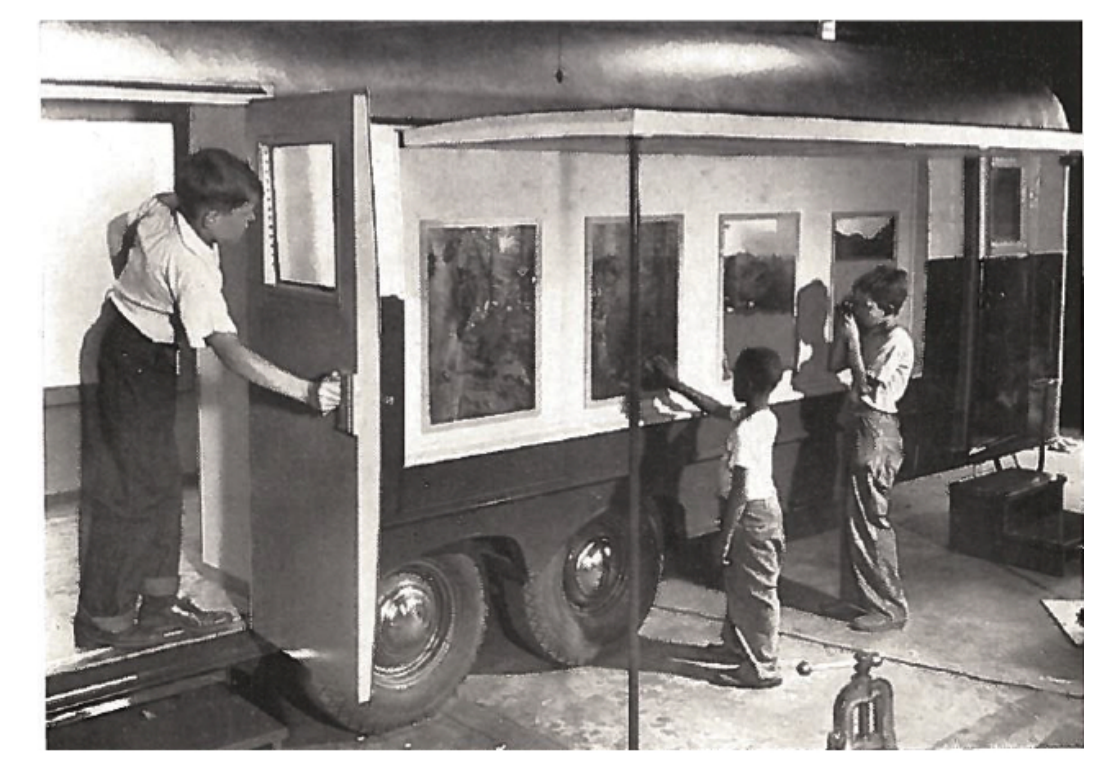

Figure 2. The Traveling Trailside Museum folding panels, outside the trailer. Photograph taken by James Thomas for the Cleveland Press [Disher, 1947]. From the Archives of the Cleveland Museum of Natural History.

In Sweden, in the early 1950s, the Teckniska Museum in Stockholm and the Swedish Society for Economic Information organised the exhibition "Economic Life in Sweden" mounted in their "exhibition bus" [Museums and Monuments V. Manual of Travelling Exhibitions]. In France, the International Children's Centre already had a mobile unit in 1958 [Unesco, 1958a] and, in the 1960s, Ukraine also inaugurated its museum on wheels, the Regional Museum, Vinnitsa-Yampol [Ševčuk, 1966]. In the 1970s, there were more than 40 mobile museum programmes in the United States and Canada [Supplee, 1974] and in the early 1980s, the US had at least 55 mobile museum units, 25 of which were about science themes [Zucker, 1983]. In 1985, Australia launched the mobile version of its science centre, the Questacon Science Circus [Gore, 2001].

It is noticeable that the idea of mobile museums was widespread internationally in the second half of the 20th century and many countries began to invest in the adaptation of vehicles to exhibition halls and travelling with their exhibitions and activities.

UNESCO's

travelling

exhibitions and its encouragement of the construction of mobile museums
The democratising "boom" that occurred after World War II also generated concern about the public communication of science and technology and the improvement of science education in UNESCO member countries [Abrantes, 2008]. The organisation's initial program was to restore the education and cultural services of war-torn countries, but this idea soon assumed a more general purpose. By the end of the war, many schools in various countries had been destroyed, which required the reconstruction of their science laboratories and new equipment to carry out scientific experiments. To that end, UNESCO published the 1948 book Suggestions for Science Teachers in Devastated Countries, which became a success not only in regions devastated by war, but in others that were devoid of such laboratories [Abrantes, 2008] and included museums as an integral part of its concerns. 
Continuous efforts were also made in the informal education sector and, as indicated by UNESCO's report [1950, p. 42], the aim was "to enable the general public to understand the practical applications of science to modern life".

In this context, the potential of travelling exhibitions was understood by UNESCO and its work had an impact on the area from the 1950s onwards. The organisation invested in publications in the area which, as well as publicising the various projects that were being developed around the world, they served as an incentive and reference for those institutions that were still planning their itinerant projects.

A whole volume in a 1950 edition of the journal Museum (which UNESCO was responsible for) was dedicated exclusively to 'Museums and circulating exhibitions', demonstrating the importance given to the theme by the organisation at that time. In 1951, the architect Abraham Beer was invited to speak about 'New Trends in Mobile Museums' at the UNESCO's Joint Meeting of Experts in Paris [Beer, 1951], and the following year, 1952, he published the paper 'Recent Developments in Mobile Units' in Museum [Beer, 1952].

UNESCO also published in 1953 the Manual of travelling exhibitions [Museums and Monuments V. Manual of Travelling Exhibitions]. The document, which dealt with how to construct, assemble and carry out mobile exhibitions, highlights UNESCO's involvement and work in the field. In 1954, Museum published a new document by Beer [1954] 'Expandable Mobile Museum for Arid Zones' in which he laid out a new extendable model that tripled the capacity of the vehicle, and whose construction plans were made available to all member states.

Another UNESCO project that impacted the field was its pioneering project of travelling science exhibitions. Between 1950 and 1960, the organisation prepared various science exhibitions that travelled to different countries. The first of these travelling exhibitions was in the areas of physics and astronomy. Between 1950 and 1952, it covered 13 Latin American countries: Peru, Ecuador, Cuba, Mexico, Guatemala, El Salvador, Honduras, Costa Rica, Panama, Colombia, Venezuela, Dominican Republic and Haiti. This exhibition, coordinated by the Brazilian engineer Hervásio de Carvalho, was composed of explanatory panels and equipment demonstrating concepts of mechanics, heat, sound, electricity, optics, nuclear physics and astronomy [Unesco, 1951; Unesco, 1954; Gille, 1954; Layton, 1995; Tavares, 2006].

Following the success of the first exhibition, UNESCO launched the second, entitled "Our Senses and the Knowledge of the World", organised in Thailand in 1951. This exhibition, which contained scientific equipment, 50 interactive exhibits and 20 panels with explanations in three languages, also visited Indonesia, Vietnam, Cambodia, the Philippines, Japan and India [Unesco, 1954; Gille, 1954; Bose, 1983].

The third exhibition was "New Materials", in 1951-1952, which dealt with the issue of new man-made materials, such as plastics, alloys and some chemicals. It visited a number of countries in Europe and in the Middle East [Gille, 1954], as well as being exhibited in Argentina [Abrantes, 2008]. Soon after, UNESCO inaugurated their fourth exhibition "Man Measures the Universe", which covered techniques and instruments used to measure size and distance, from the intra-atomic to the intergalactic, in 1954, held in member countries of the European Community [Petitjean et al., 2006]. 
In 1956, the fifth exhibition "Energy and its transformation" travelled to Singapore, Malaysia, Thailand, Vietnam, Philippines, Taiwan and New Zealand [Bose, 1983]. The following year, the exhibition "The Earth as a Planet" was opened in France, Belgium and the United Kingdom [Unesco, 1958c]. UNESCO also proposed, in 1959, two exhibitions: one on the issue of automation and another called "The Galapagos Islands: evolution's show-window" [Unesco, 1959a; Unesco, 1959b].

Although these exhibitions were not installed in vehicles (they were only travelling exhibitions), it is important to highlight them in this context, since those that circulated in Asia were crucial to inspiring the creation of several science museums in India [Bose, 1983]. Among them are the Birla Industrial and Technological Museum, in Kolkata, the Visvesvaraya Industrial and Technological Museum, in Bangalore, and the Nehru Science Center, in Mumbai. They also encouraged the creation of the national mobile exhibition program to serve the country's rural population, inaugurated in 1965 [Ghose, 1968; Ghose, 1986; Maitra, 1997; Mukhopadhyay, 2005]. Along with the success of the programme in India, other Asian countries also invested in the creation of mobile exhibitions: in 1980, Sri Lanka launched its first mobile museum and, in 1982, the Center for Educational Museums in Bangkok, Thailand, set up its two mobile units and The Republic of Korea introduced travelling science exhibitions which comprise items selected from the nation's annual science fair by the National Science Museum in Seoul [Bose, 1983].

Finally, UNESCO played a decisive role in the creation of the first mobile unit for public communication of science in Africa. As reported by Daifuku [1965], the organisation was in charge of building an experimental mobile museum in 1962. A few years later, the mobile museum was launched, presenting an exhibition borrowed from the French museum, Palais de La Decouverte.

The literature shows that, up to the middle of the 20th century, a broad-based movement for the creation and development of mobile museums and travelling exhibitions in Europe, the USA, Asia and Africa was the result of a conviction that these initiatives could contribute to expansion of access to science and technology by the population, especially those that lived outside large urban centres.

The informational perspective, focused on the wide dissemination of ideas and concepts of science and technology, seems to have dominated the initiatives and, undoubtedly, the support of UNESCO was essential for the projects to be carried out.

It is relevant, however, to point out, based on the work of Bonatto [2012], that in the post-war period, with the onset of the Cold War, there was a true "crusade" for security, mainly led by the United States (alongside initiatives of the UN) aimed at rebuilding education in the affected countries. For this author, based on the works of Leher [1999] and Kotchetkov [2010], UNESCO was concerned with the dissemination of a functional cognitive and ideological source for the construction of capitalist social behaviours, seeking to promote, in the midst of conflicts and challenges, the ideology of peace, and cultural values that include technology as culture under the protection of the World Bank. From this perspective, UNESCO's missions were focused on establishing scientific and technological infrastructure for the new and independent developing countries and the services were related to the preparation of development plans for these countries. Thus, UNESCO played a key role in the development of science and technology policies for developing 
countries. No wonder this period was also marked by the development of mobile science programmes in Brazil, as we will see next.

Travelling science exhibitions and mobile museums and centres in Brazil
In Brazil, the creation of circulating scientific exhibitions - without vehicles in its main infrastructure - by educational and research institutions, museums and scientists also dates back to the first half of the twentieth century. The National Museum in Rio de Janeiro, for instance, loaned and circulated collections and natural history didactic charts from 1927, offered by the museum's education department created by Roquette Pinto [Pereira, 2010; Moreira, Massarani and Aranha, 2008]. Another example of a travelling scientific exhibition in this period was one organised by José Reis, who toured the interior of the state of São Paulo from 1934 to 1938. With the support of the Agricultural Cooperative of Mogi das Cruzes (SP), Reis set up a mini-lab in a van, to inform farmers about bird diseases and how to prepare vaccines, as well as recommending and distributing medicines [Nunes, 2007; Abrantes, 2008].

After the 1950s, this type of travelling activity was strengthened in the country because of international influence on the areas of museology and science education and communication and, some part, because of the encouragement of UNESCO. The seminars and roundtables on museums arranged by the organization, in the various countries involved, left significant marks with regard to the educational role of museums [Valente, 2008]. In the particular case of Brazil, the seminar took place in 1958, in Rio de Janeiro. In the document produced [Unesco, 1958b; Rivière, 1960], it is highlighted the relevant role of mobile museums and travelling exhibitions and the UNESCO's publications on the theme - such as 'The Manual of Travelling Exhibitions' [Museums and Monuments V. Manual of Travelling Exhibitions] and 'Recent developments in Mobile Units' [Beer, 1952] — are mentioned as references.

UNESCO's direct action in stimulating itinerant activities in Brazil came about through the creation of the Brazilian Institute of Education, Science and Culture (IBECC), which had as one of its first activities the implementation of scientific exhibitions. In 1954, the exhibition "The atom" was organised by Aristóteles Orsini and Isaías Raw [Abrantes, 2008]. The success of the venture led UNESCO to sponsor the event, including it in its travelling science exhibition project, taking it to three Argentinian cities in the following year [Raw, 1970; Abrantes, 2008]. In 1962, IBECC presented at the XIV Annual Meeting of the Brazilian Society for the Progress of Science a travelling laboratory, in which chemical demonstrations and experiments were carried out, which could reach schools throughout the country [Abrantes, 2008].

Besides IBECC, other institutions have invested in the production of travelling science communication activities. Aiming to promote the benefits of nuclear energy, the travelling exhibition sponsored by the Atomic Energy Council, "Atoms in Action", which was exhibited in several countries, also came to Brazil. The National Nuclear Energy Commission promoted the event in the cities of Rio de Janeiro, São Paulo and other capitals in 1961. The exhibition presented the advantages of this new energy source by communicating information about its applications in scientific research, industry and health, and using images and arguments to distance science from war [Andrade, 2012]. It is also important to 


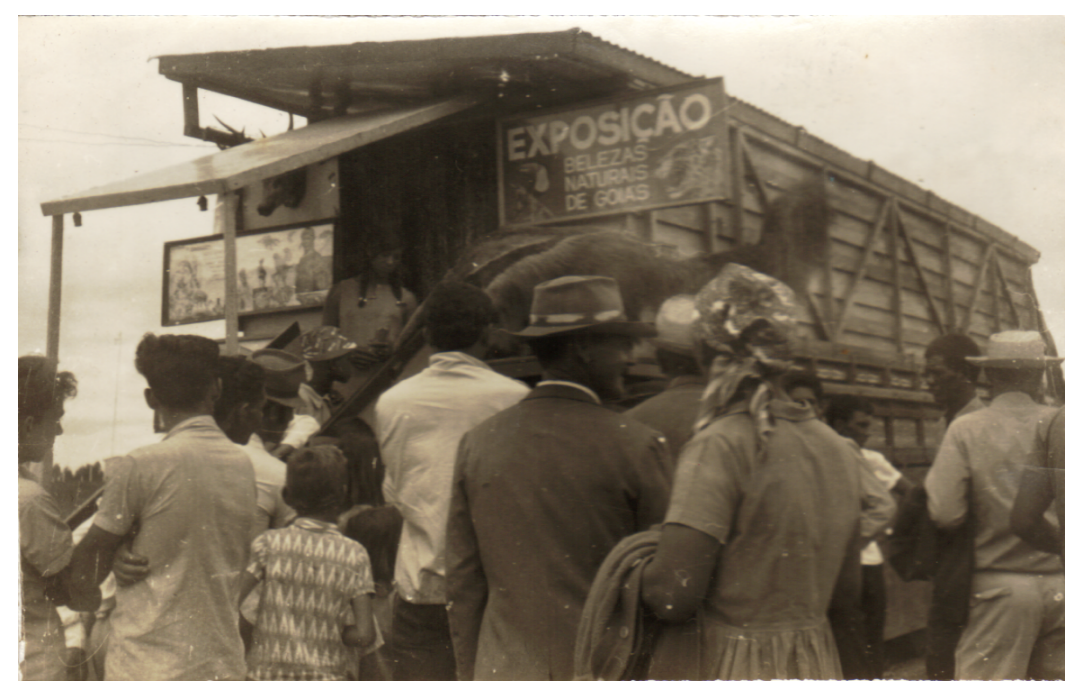

Figure 3. José Hidasi Mobile Museum built in an ox cart in the city of Anápolis, Goiás, Brazil (1969). From José Hidasi personal arquives. Image permission: Roberta Morais.

mention other travelling science communication experiences developed by museums and scientific institutions in the country in the following years, such as the activities of the "Espaço Ciência Viva" (Living Science Space), in 1982, in Rio de Janeiro; of the Emílio Goeldi Museum, in Pará, in 1983, and of the project "O Museu vai à Praia" (The Museum Goes to the Beach) of the Museum of Astronomy and Related Sciences (MAST), in 1987 [Gaspar, 1993; Mingues, 2014].

Despite these various travelling projects having been implemented in the country, none of these had a vehicle at the core of its infrastructure. The first example of a museum on wheels with a scientific theme is the already-extinct José Hidasi Mobile Museum, created in 1965 in the state of Goiás, as the historical survey conducted by Xavier [2012] shows. Initially, it was built in an adapted ox cart (Figure 3) and then was transferred to a bus (Figure 4), with its internal space also adapted to an exhibition hall. The museum, which aimed to popularise the biological sciences, was composed of different species of animals. It stayed on the road for nearly two decades and was maintained by its Hungarian founder, José Hidasi, who had moved to Brazil during the Second World War [Perotti, 2005].

After the José Hidasi Mobile Museum, the first museum that acquired a truck with the function of transporting the exhibition and transforming it into an auditorium and exhibition venue, was the Promusit (Mobile Museum Project) from the Museum of Science and Technology from the Pontifical Catholic University of Rio Grande do Sul (MCT-PUCRS). This mobile science museum implemented in 2001 in the state of Rio Grande do Sul, was mainly funded by the Vitae Foundation and inspired by the Australian Shell Questacon Science Circus [Bertoletti, 2004; Vitae, 2006].

This successful initiative stimulated the creation of similar projects in the country. In 2004, the public call for tenders for the financial support for mobile science projects, held by the Brazilian Academy of Sciences (ABC) and the Ministry of Science and Technology (MCT), marked the institutionalisation of the idea. 


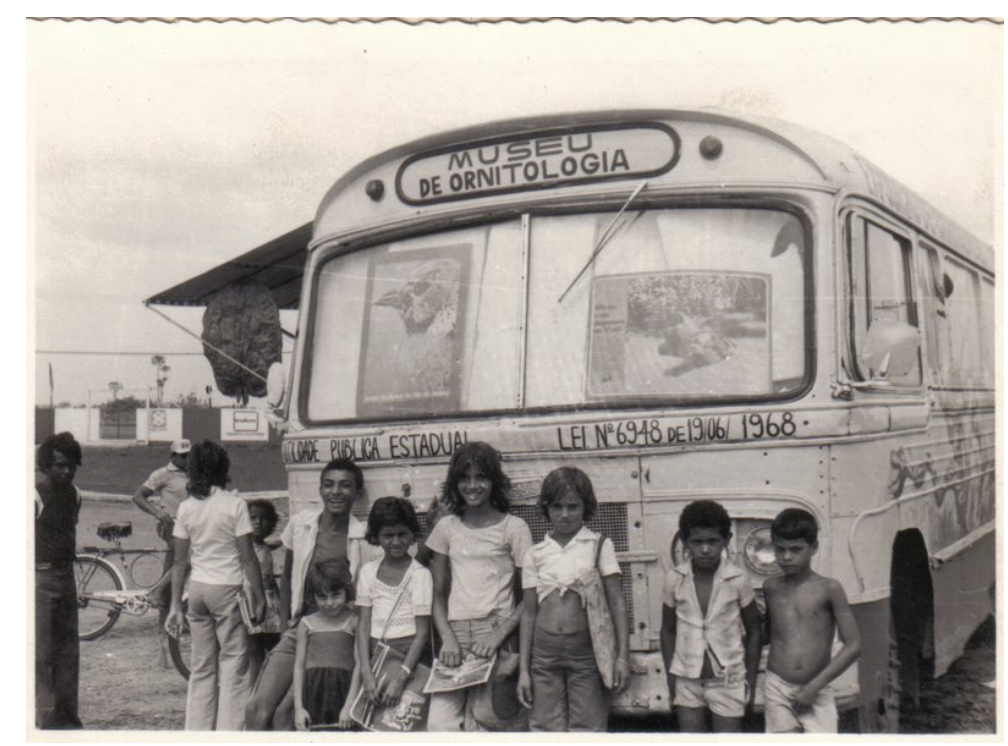

Figure 4. José Hidasi Mobile Museum built in a bus in the city of Pirenópolis, Goiás, Brazil, (1979). From José Hidasi personal arquives. Image permission: Roberta Morais.

The public tender supported the implementation of projects which aimed to use vehicles adequately-equipped for excursions around large cities or through rural areas of the country aiming "to awaken and encourage awareness and interest for the search for knowledge and understanding of the world, through the granting of support to the development of the popularisation and communication of science" [ABC, 2004, p. 1].

In research conducted of archives and documents relating to this public tender, located in the archives of MAST and ABC, we identified that 48 proposals were received from all five regions of the country (North, Northeast, South, Southeast and Center-West) and from 12 of the 27 states: Rio de Janeiro, São Paulo, Minas Gerais, Paraná, Rio Grande do Sul, Santa Catarina, Bahia, Paraíba, Pará, Amazonas, Pernambuco and Distrito Federal. A boat, lorries, trailors, minibuses, vans and cars were requested. Most of the proposals were submitted by recognised universities and educational and research institutions which worked in several fields of knowledge, as well as by municipalities and nongovernmental organisations. Thus, having analysed the merit and feasibility of each project, the public tender provided financial resources for the implementation of nine of these projects, chosen so as to include all regions of the country: 1) a minibus for the project "Novos Curupiras" (Pará); 2) a minibus for "Espaço Ciência" (Science Space) (Pernambuco); 3) a lorry for the State University of Santa Cruz (Bahia); 4) a van for the project "Ciência para Poetas" (Science for Poets) by "Casa da Ciência" (House of Science) of the Federal University of Rio de Janeiro (Rio de Janeiro); 5) an articulated trailor for the project "Ciência Móvel" (Mobile Science) by the Museum of Life of the Oswaldo Cruz Foundation (Rio de Janeiro); 6) a minibus for the University of Brasília (Distrito Federal); 7) a minibus for the project "Sangue na Rua" (Blood on the Street) by the State University of São Paulo (São Paulo); 8) an articulated tractor trailer for the project "Laboratório Itinerante Tecnologia Com Ciência" (Mobile Laboratory Technology with Science) of the Federal University of Rio Grande do Sul (Rio Grande do Sul); 9) Funding for the already created "Promusit" (MCT-PUCRS) (Rio Grande do Sul) [Brasil, 2008, p. 17]. 


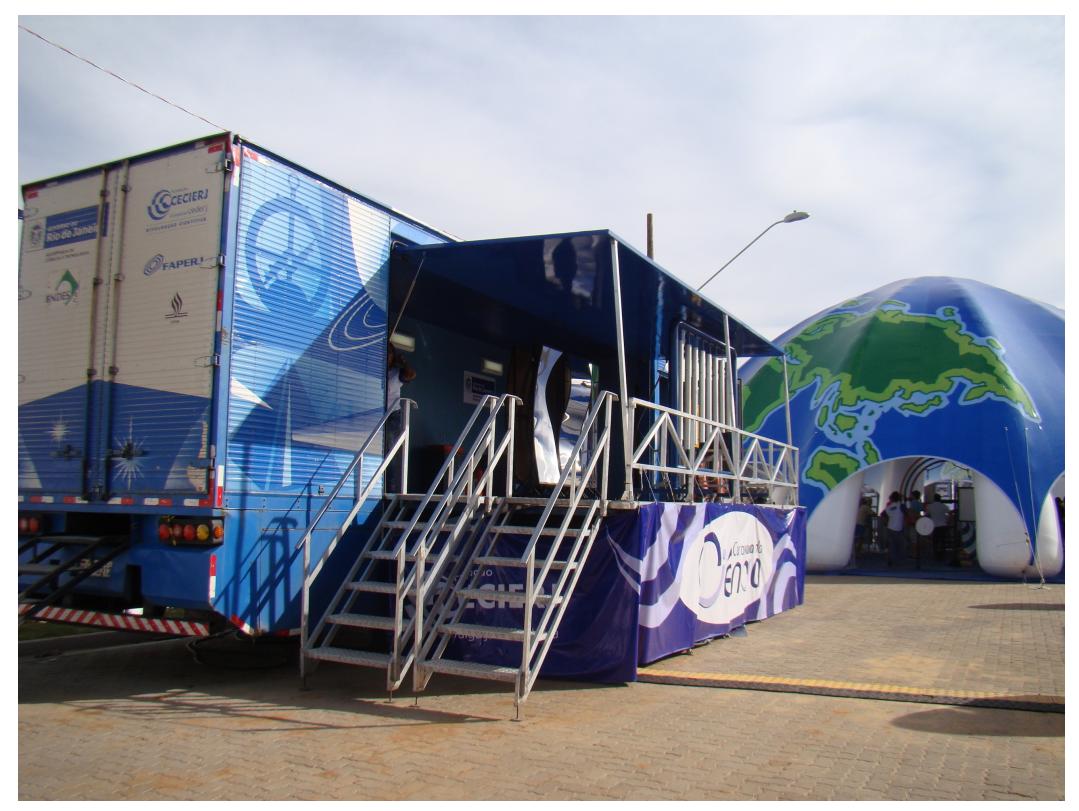

Figure 5. Caravan of Science adapted and articulated tractor trailer and its inflatable tent, in the city of São Carlos, São Paulo, Brazil (2015). From Caravan of Science Arquives.

Other tenders for proposals of popularisation of science and technology projects from the federal government and from several state funding agencies continued until 2015. Other mobile science projects were contemplated and inaugurated over the years with the support of public funding from agencies such as the Ministry of Science and Technology (MCT), state secretariats of science and technology, the National Council for Technological and Scientific Development (CNPQ), the federal Funding Authority for Studies and Projects (FINEP), state foundations of research support (FAPs), the Brazilian Development Bank (BNDES), the Vitae Foundation and others. In 2006, for instance, the Rio de Janeiro state government, MCT, BNDES and the Vitae Foundation financed the creation of the mobile science centre, Caravan of Science, by CECIERJ Foundation of the Science and Technology Secretariat of the State of Rio de Janeiro (Figure 5) and, in 2007 and 2008, the Federal University of Minas Gerais received funding from the Minas Gerais Research Support Foundation (FAPEMIG) and from the MCT for the construction of the PONTO UFMG Itinerant Museum, which was inaugurated in 2012.

In 2015, the Brazilian Association of Science Centres and Museums (ABCMC) listed 32 travelling science programs in the country [Almeida et al., 2015]. We should note, however, that some of them do not have a vehicle. Based on data collected in the field by visits to some institutions, in presentations of these experiences in academic events and in research of official documents and websites, it was possible to identify those which have vehicles integrated in their main infrastructure, as well as other mobile science museums and centres that were not listed by Almeida et al. [2015]. These totalled 34, organized in different types and formats.

This research showed us that, currently, all regions of the country have mobile units, however, their distribution is quite uneven. The North region of the country has two: the "Ilha da Ciência" (Science Island) by the Federal University of Maranhão and the "Clorofila Científica e Cultural dos Mangues" (Scientific and Cultural Chlorophyll of the Mangroves). In the Northeast, there are eight mobile 


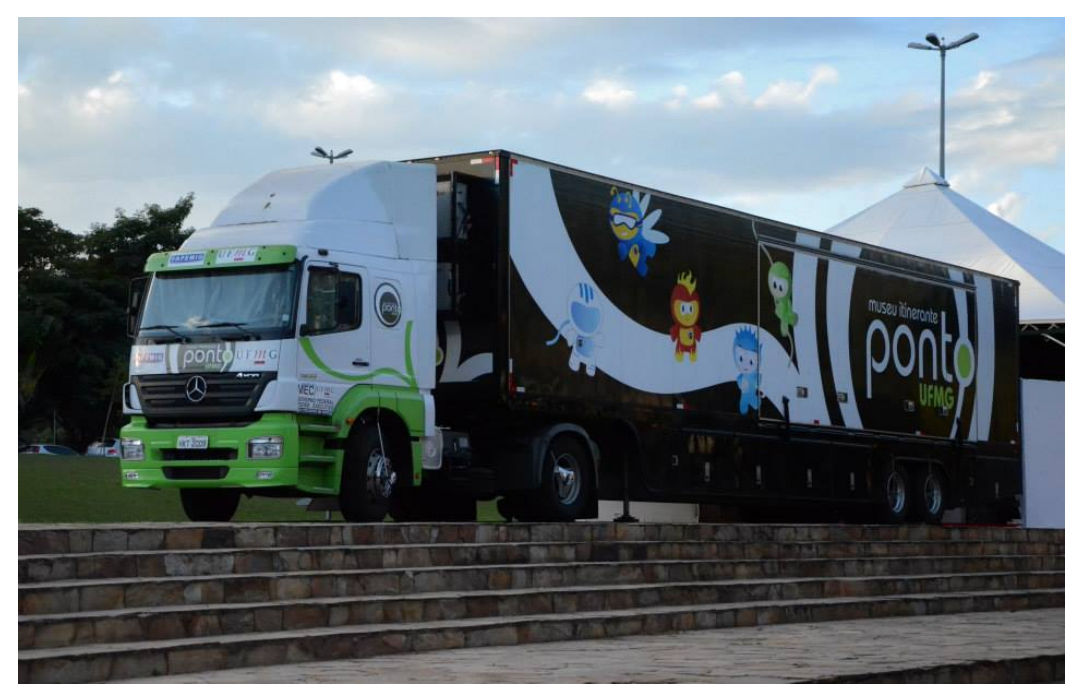

Figure 6. PONTO UFMG Itinerant Museum in the city of Belo Horizonte, Minas Gerais, Brazil (2014). From the Arquives of PONTO UFMG Itinerant Museum.

units, among which are: "Mobile Science" by the State University of Bahia, the "Caminhão com Ciência" (Lorry with Science) of the State University of Santa Cruz (Bahia) and the "Ciência Itinerante" (Travelling Science) of the Science and Technology Secretariat of Ceará. In the Midwest, there are three: the "Experimentoteca Móvel" (Mobile Experiment Space) by the University of Brasília, the truck "Nossa Energia" (Our Energy) by the region's electric utility, and the "Circuito itinerante - MT Ciências" (Science Touring Circuit - MT Science) of the Science, Technology and Innovation Secretariat of the State of Mato Grosso, which is being refurbished and will be inaugurated by the end of 2017. In the South region, there are five. Among them, the Promusit of MCT-PUCRS and the truck "SESI Science". Finally, the Southeast region has the highest concentration, with 16. Among them are: "Ciência Móvel: vida e saúde para todos" (Mobile Science: life and health for all) by the Oswaldo Cruz Foundation, the Caravan of Science by the CECIERJ Foundation; the PONTO UFMG Itinerant Museum (Figure 6) and the "Oficina Desafio" (Challenge Workshop) by the Exploratory Museum of Science of the State University of Campinas.

Having outlined this brief history of the creation of mobile science museums and centres, we posit that the emergence of these initiatives occurred through the influence of international developments in the fields of science communication, education and museology, but in Brazil, it also depended essentially on a national policy supported by funding and other assistance from the federal and state governments, and from the support of non-governmental organisations, such as the Vitae Foundation, from the 1990s onwards. It is appropriate, however, to situate this within the social context of Brazil during the 1980s and 1990s.

As Bonatto [2012] indicates, this period was characterised as a threshold "between the end of the repressive regime of the military dictatorship and the outline of a complex social organisation which emerged and expressed itself in the form of political parties, trade unions, student organisations and civil associations". It was in this context that the Vitae Foundation was created in Brazil (1984), which resulted from the dissolution of the South American Hochschild Companies, a 
business group responsible for mining companies, which has since then been directed towards social purposes. According to Bonatto [2012] , in agreement with Vitae's final report [2006], the purpose of the foundation, as well as its other affiliates, was "to stimulate the philanthropic spirit" and "contribute to the improvement of the living conditions of their communities, promoting projects in the areas of education, culture and social promotion."

Vitae worked for a limited period with the capital it received, in order to guarantee larger investments linked to solving problems of greater social reach, with investments in the fields of culture, social promotion and education. As Bonatto [2012] states, such a policy has particularly benefited museums and science centres, technical and agrotechnical schools, as well as social institutions dedicated to complementary education. Thus, from 1990, Vitae started to expand the informal education of science, through technical and financial assistance to centres and interactive science museums.

These aspects highlight the role of financing policies in the construction of museological initiatives in the country, and, within them, the mobile science museums and centres, inserted into a political context created for the formation of a tolerant worker profile, aimed at a competitive market, and for organisations in the education sector. The vision of science that is reinforced is summarised by Bonatto [2012, p. 266]:

\begin{abstract}
Another aspect is that Vitae enabled the emergence of institutions that reproduce a global superstructure supporting the public communication of science and technology as a neutral ideology that plays a central role in the formation of a new society focused on the consumption of automation technologies, as well as in the preparation of intellectuals organising a new working class conformed to the consensus in a "knowledge society", which is based on the individual responsibility of the worker for his successes and failures.
\end{abstract}

In light of the aforementioned aspects, we would like to reflect on some of the contemporary challenges to the development of mobile science museums and centres.

\section{Current challenges and final considerations}

We have shown that mobile science communication activities underwent significant expansion worldwide after the Second World War and these actions continue to have great potential for reaching people, in different places, in different ways. From this perspective, we consider that one of the rewards of travelling exhibitions and mobile museums is the possibility of fostering social inclusion through the offer of cultural and scientific activities, in places where people usually do not have access.

Throughout our studies, one of the recurrent discourses related to these initiatives is to enable social inclusion through access to knowledge. According to Beer [1952], the mobile units were required firstly in large cities, to serve the different neighborhoods and regions of the city; secondly, in small cities and rural areas, distant from large urban centres; and, thirdly, in poor and under-developed countries or in those devastated by the Second World War, in the absence of basic 
education. As stated by Osborn and Morley [1963, p. 56], such experiences “(...) bring to the remote places the possibility of knowledge and enjoyment of the arts, sciences and history provided for large centres of population by great museums and exhibiting organisations".

UNESCO was one of the institutions that endorsed this mission, as demonstrated by the document Report concerning the possibility of establishing international regulations on the most effective means of rendering museums accessible to everyone [1958a, p. 8], which declares that "A new principle must be recognized as a basic condition of the existence of museums, namely, that they must be accessible to all without regard to economic or social status."

Nowadays, outside of Brazil, this type of project can be seen in all regions of the globe, in countries such as India, USA, United Kingdom, Australia, Mexico, France, Germany, Turkey, Sweden and China [Gore, 2001; Barmby et al., 2005; Ghose, 2015; Rees, 2016; Cors, 2016; Jones and Stapleton, 2017]. There are, however, some variables and challenges involved in the creation, maintenance and existence of these initiatives, connected to both the conceptions of science and of public communication of science that they promote, as well as the scientific, economic and social policies that are linked to the financing agencies that impact their development and determine their performance among different audiences.

In our literature review, we have found few published studies on the current status of this type of science communication activity, its scope and its impact. As we lack detailed analyses with expanded data, particularly regarding the quantity and quality of these kinds of actions globally, we shall not attempt such a task here, because it demands more in-depth research. We will, therefore, limit ourselves to outline three general challenges applied to the Brazilian context based on the literature consulted, professional experience, field research, interviews and reports of actors directly involved in the activities.

\section{Challenge 1. Financial and political support}

The first challenge for mobile science museums and centres is financial and political support. In addition to initial funding for the construction of a mobile museum (such as the purchase of the vehicle and its adaptation, and the acquisition and assembly of the exhibition), the mobile unit, in the long-term, by itself, is an expensive activity and requires specific administrative processes and travel logistics which are quite costly.

The maintenance of the travelling infrastructure, exhibition, equipment and the vehicle must be continuous and is generally more expensive than ordinary museum structures, as there is a greater wear on this infrastructure due to routine dislocation, assembly and disassembly. At the same time, this structure also needs to have insurance against accidents or damage that may occur during travel and the further the destination of the mobile museum, the greater the costs of fuel, human resources and transportation.

As mobile science museums and centres are key stakeholders in a public science communication, many are part of governmental bodies and non-profit foundations. 
In Brazil, they current rely heavily on public money for their construction and maintenance. For this reason, financial sustainability is one of the contemporary challenges as there is no way to develop such ventures without the strong political and financial support of funding agencies and institutions. Therefore, on the one hand, the political dimension must be well aligned with educational and cultural missions in order to be able to implement and maintain mobile museums. On the other hand, we know that these educational and cultural goals are not neutral. There are ideals, interests, determinants, conceptions and different actors, in diverse spheres of society, that influence and condition the format that this political and financial support will have.

In raising aspects of the financing history of these projects, we have shown that other institutions, besides government agencies, were present and fundamental for the implementation of travelling exhibitions and mobile museums. UNESCO was the promoter of important international and national projects throughout the twentieth century and, in Brazil, some government agencies and the Vitae Foundation assumed this role. While funding and funding agencies are crucial to the existence of these initiatives (which must be strengthened - they are highly important for the growing access of the population to science and technology) they also shape certain conceptions of science and technology, work and worker, economy and, ultimately, society.

Coupled to this is the isolation and institutional vulnerability of these activities. In the Brazilian context, the development of public policies and prioritisation of the area in governmental action is still necessary. Although there was a specific national public tender for the creation of mobile science projects in 2004, which encouraged the idea in the country and had high demand, this was a one-off action and not a policy of continuous funding from government and funding agencies. Since 2004, other tenders for science popularisation projects have been launched and some mobile science projects contemplated. However, due to a number of issues, challenges and problems that still need to be studied and explored, many have not been realised and some have opened and been discontinued over time. The issue of public policies affects not only the itinerant actions, but the public communication of science in general, as Massarani and De Castro Moreira [2016, p. 1593] point out:

\footnotetext{
Despite the advances of the last decade in terms of encouragements and resources from the federal and from several state governments, public policies still are incipient. Existing structures need to be strengthened and new stimulatory policies should be created, continuity and expansion of means and resources are needed. Science communication has already entered into several governmental agendas and in many educational and research institutions. Politically, however, this has not been done to the necessary extent and to the level of investment inflow that would be needed to get a more socially broad, inclusive and qualified performance.
}

From this perspective, critical analysis of the determinants, conceptions, actors, agencies and different spheres of society that promote, constrain and determine the elaboration of exhibitions and educational projects, whether mobile or not, is still rare in studies on science museums and centres, but there is already some research from this perspective [Marandino, 2016; Achiam and Marandino, 2013; Bonatto, 
2012; Navas, 2008]. Hence, it is fundamental to promote research and reflection on the external and internal constraints that influence and determine the development of mobile experiences in order not only to better instruct financing policies, whether governmental or non-governmental, but also to equip the institutions to effectively carry out these actions.

\section{Challenge 2. Partnerships, science communication and human resources}

The second challenge concerns the daily practice of mobile science museums and centres, which involves the relationship with institutional partners and municipalities, the model of communication of science implemented and the constitution of a team to work "on the road". When travelling, mobile museums depend on the establishment of institutional partnerships with the government and with private companies based in the destination municipalities, such as city governments and their secretariats of education, science, technology and culture, schools and other actors of interest. This is because the arrival, installation and offer of services involve the logistics of an event in which a large audience is reached (mainly from the city itself and from neighbouring cities). Thus, transport, public safety, commerce and educational institutions need to be mobilised for the proper functioning of the enterprise. Problems and unexpected events are common factors, and their negotiation, logistics and management, are always a critical point for those who are leading and coordinating these itinerant activities.

Another factor related to mobile museums' practice is the science communication model they assume. They have great potential to carry out a socially relevant mission by enabling access to scientific knowledge and science popularisation activities by various types of public and, specially, by those who are often neglected (by economic, social and geographical conditions). However, experience has revealed that many of the recurring discourses on these initiatives repeat and perpetuate the idea of communication of science in a deficit model.

This conception can be found in institutional documents, projects and reports (mainly in those involving funding), expressed in its institutional mission and justifications for the relevance of mobile museums. We know that it is necessary to develop research to broadly and deeply evaluate the models of communication practised by these actions, but it is possible to affirm that very often the prevailing concept is of "bringing" the knowledge to people in an imperative, top-down, way, in which experts (i.e., museums, research institutions, universities, scientists) make knowledge available to the lay population, favouring the deficit model [Bauer, Allum and Miller, 2007; Bauer, 2016; Cortassa, 2016].

It is known that museums and science exhibitions in Brazil emphasise the deficit model of communication [Moreira and Massarani, 2002] and there are few experiences that deal with the communication of science in a dialogical way, in an emancipatory praxis [Bonatto, 2013] and addressing issues of science, technology and society and of the unfinished science [Hine and Medvecky, 2015], as shown by some initiatives analysed by Contier [2009], Cerqueira, Genova and Bizerra [2014] and Pinto [2014]. It is possible that mobile science museums and centres in the country also do not escape this tendency. We wonder, therefore, whether it is necessary to develop research on the relationship of these museums with their 
audiences and, in particular, to establish more dialogic venues with the communities visited, seeking the exchange of knowledge, integrating local actors and knowledge, and providing access to critical and quality education and communication.

The issue of accessibility is another major challenge for mobile museums. Currently, museums in Brazil are being required to eliminate their physical, political, attitudinal and communicational barriers and change to be accessible to a diverse range of public, especially those with disabilities. Although advances are being made, both in Brazilian legislation and in practice, the process is still slow [Tojal, 2007; Tojal, 2015]. Faced with this difficulty, some mobile museums, such as the Caravan of Science (Cecierj Foundation), are already working to improve their accessibility, developing studies, training their teams and implementing structural modifications [Inacio, 2017]. Nevertheless, studies on the subject and more public investment are still needed.

Finally, the last aspect of this challenge is related to team organisation. Mobile science museums and centres in Brazil value human mediation as the key point of connection among the institution, the exhibition and its audiences. However, the constitution of this team, its training and articulation is not a simple task to be implemented. Employees who work in mobile activities need to have a unique profile that encompasses, being a good communicator of science, a willingness to stay several days away from home and to face the routine and the challenges imposed by travelling. Added to this, there is still the lack of formalisation of the profession of explainers in science museums and centres and little investment in their formation [Carlétti and Massarani, 2015]. As explained by Costa, Norberto Rocha and Poenaru [2014] regarding team training for the PONTO UFMG Itinerant Museum,

The first challenge is directly related to the museum's travel dynamics: At least one trip per month for at least five days. This results in the inability to compose a fixed team for travelling, since most of them are students, have other jobs, and therefore cannot leave one week a month to go along with the museum. Thus, it becomes essential to maintain a database of updated, trained available team to be called to each trip [Costa, Norberto Rocha and Poenaru, 2014, p. 56].

To overcome this challenge, some mobile museums are proposing a programme for training volunteer explainers in the destination to comprise 30 to 40 per cent of the staff needed to serve the audience. This strategy is being carried out, for example, by PONTO UFMG Itinerant Museum and by the Caravan of Science (Cecierj Foundation) [Costa, Norberto Rocha and Poenaru, 2014; Norberto Rocha, 2015].

\section{Challenge 3. Research and evaluation of impact}

The third and last challenge we highlight is the need to do more studies and critical analysis on the role, potential, effects and impacts of these mobile science museums and centres regarding their direct relationship with their audience. Additionally, it is necessary to document their creation, conception, activities and evaluation.

In Brazil, the few records available on mobile science museums and centres were and are mostly carried out by their own teams and are often still incomplete, given 
the complexity of implementation and the activities of these projects. Apart from a bibliographical study carried out in this context, for example, we could identify few published academic works that had mobile science museums, centres and projects, and their activities, as the research topic and/or as the site of data collection. These are: Gonçalves [2010], Schwenck [2011], Xavier [2012], Ferreira et al. [2012], Gonçalves [2014] and Pinto [2014]

Also, although we could identify some studies analysing mobile initiatives in the international context [Barmby et al., 2005; Cors, 2013; Cors, 2016; Cors and Robin, 2016], evaluations in Brazil still rely largely on attendance numbers and requests for visits, added to the miles travelled. Research that involves analysing the potential of exhibits, apparatus, activities and that assess their impact on the audience is necessary and should be promoted to evaluate the contribution of these experiences from the point of view of the public communication of science, and science literacy and education. As Bucchi and Trench [2014] indicate, after many years discussing practices, experiences and theories about science communication and public understanding of science, there is a need to develop tools based on indicators to evaluate and analyse institutional performance:

Public communication of science should now be mature enough to pass from a heroic phase, in which everything goes for the sake of communicating science to a phase in which quality criteria are central for all parties involved. This implies developing indicators and standards of performance, particularly for institutions, and assigns added importance to the issue of evaluation [Bucchi and Trench, 2014, p. 10].

In Brazil, there is a concern with the analysis of the impact of science communication actions and scientific literacy processes in museums and science centres. Recently, academic studies in informal science education are using an indicator-based framework to analyse the processes of scientific literacy involved in a variety of contexts, namely: Cerati [2014], Mingues [2014], Oliveira [2016] and Lourenço [2017]. This framework is also being applied to the analysis of the exhibitions of four Brazilian mobile science museums and centres, and it will soon be able to provide an overview of how they can contribute to their audience's scientific literacy [Norberto Rocha, 2016; Norberto Rocha, ND].

In short, it is possible to argue that mobile science museums and centres provide a vast area of study in the field of public communication of science and we do not intend in this paper to exhaust the numerous spheres of its history in the public communication of science, as well as its challenges. Issues concerning its history, funding, motivations (political, institutional, ideological, etc.), travel and actions constitute a rich material to be studied. We, thus, are convinced that they have great potential to promote science and knowledge as an important instrument to overcome underdevelopment and social issues. However, it is also necessary to carry out critical and ground-based analyses of the projects already developed and those that are under way, to inform public and institutional policies to finance these initiatives. There is, without doubt, a long road to be travelled, which requires public policies, financing and collective action by institutions and professionals involved in scientific work and its communication. 
ABC (2004). Edital de Chamada Pública de Projetos ABC No 01/2004 — Projeto Ciência Móvel. Rio de Janeiro, Brazil: Academia Brasileira de Ciências.

Abrantes, A. C. S. (2008). 'Ciência, Educação e Sociedade: o caso do Instituto Brasileiro de Educação, Ciência e Cultura (IBECC) e da Fundação Brasileira de Ensino de Ciências (FUNBEC)'. Tese de Doutorado. Rio de Janeiro, Brazil: Fundação Oswaldo Cruz.

Achiam, M. and Marandino, M. (2013). 'A framework for understanding the conditions of science representation and dissemination in museums'. Museum Management and Curatorship 29 (1), pp. 66-82.

DOI: $10.1080 / 09647775.2013 .869855$.

Alexander, E. P. (1979). Museums in Motion: an introduction to the history and function of museums. Nashville, TN, U.S.A.: American Association for State and Local History.

Almeida, C., Brito, F., Ferreira, R., Massarani, L. and Amorim, L. (2015). Centros e Museus de Ciência do Brasil. Rio de Janeiro, Brazil: ABCMC, Casa da Ciência/UFRJ, Museu da Vida.

AMNH (1927). Annual Report, 1927. New York, U.S.A.: American Museum of Natural History.

Andrade, A. M. R. (2012). 'Átomos na poliìtica internacional'. Revista Iberomaericana de Ciencia, Tecnología y Sociedad 21 (7), pp. 113-140.

URL: http://www.revistacts.net/index.php?option=com_content\&view=art icle\&id=473: atomos-na-politica-internacional\&catid=113: dossier.

Barmby, P., Kind, P. M., Jones, K. and Bush, N. (2005). Evaluation of Lab in a Lorry. Final Report. Durham, U.K.: Durham University.

Bauer, M. W. (2016). 'Results of the essay competition on the 'deficit concept'. Public Understanding of Science 25 (4), pp. 398-399. DOI: 10.1177/0963662516640650.

Bauer, M. W., Allum, N. and Miller, S. (2007). 'What can we learn from 25 years of PUS survey research? Liberating and expanding the agenda'. Public Understanding of Science 16 (1), pp. 79-95. DOI: 10.1177/0963662506071287.

Beer, A. (1951). New Trends in Mobile Museums. Paper presented at Joint Meeting of Experts. Paris, France.

- (1952). 'Recent Developments in Mobile Units'. Museum International 5 (3), pp. 186-195. DOI: 10.1111/j.1468-0033.1952.tb00187.x.

- (1954). 'Expandable Mobile Museum for Arid Zones'. Museum International 7 (2), pp. 127-140. DOI: 10.1111/j.1468-0033.1954.tb00247.x.

Bertoletti, J. J. (2004). Museus: uma nova modalidade de ensino. Personal communication. Rio de Janeiro, Brazil: Portal Brasiliana. URL: http://www f fioc ruz.br/brasiliana/cgi/cgilua. exe/sys/start.htm?infoid=97\&sid=31.

Bonatto, M. P. O. (2012). 'A criação dos Centros Interativos de Ciência e Tecnologia e as Políticas Públicas no Brasil: uma contribuição para o campo das ciências da vida e da saúde'. Tese de Doutorado. Rio de Janeiro, Brazil: Fundação Oswaldo Cruz.

- (2013). 'Centros Interativos de Ciência e Tecnologia: por uma práxis emancipatória'. In: Atas do IX Encontro Nacional de Pesquisa em Educação em Ciências - IX ENPEC. Águas de Lindóia, SP, Brazil.

Bose, A. (1983). Mobile Science Exhibition. Calcutta, India: Unesco Regional Office of Science, Technology for South and Central Asia.

Brasil (2008). Relatório de Avaliação do Plano Plurianual 2004-2007: exercício 2008. Brasília, Brazil: Ministério do Planejamento, Orçamento e Gestão e Secretaria de Planejamento e Investimentos Estratégicos. 
Bucchi, M. and Trench, B., eds. (2014). Routledge Handbook of Public Communication of Science and Technology. 2nd ed. London, U.K. and New York, U.S.A.: Routledge. URL: https ://www .routledge . com/Routledge-Handbo ok-of-Public-Communication-of-Science-and-Technology-Second/BucchiTrench/p/book/9780415834612.

Carlétti, C. and Massarani, L. (2015). 'Explainers of science centres and museums: a study on these stakeholders in the mediation between science and the public in Brazil'. JCOM 14 (02), A01. URL: https://jcom.sissa.it/archive/14/02/JCOM_1402_2015_A01.

Cerati, T. M. (2014). 'Educação em jardins botânicos na perspectiva de alfabetização científica: análise de uma exposição e público'. Tese de Doutorado em Educação. São Paulo, Brazil: Universidade de São Paulo.

Cerqueira, B. R. S., Genova, J. G. and Bizerra, A. F. (2014). 'Ciência, Tecnologia e Sociedade em uma exposição científica internacional: o "Túnel da Ciência 3.0" no Brasil'. Revista da SBEnBio 7.

Chalowski, K. (1950). 'Circulating exhibitions in the museums of Poland'. Museum 3 (4), pp. 275-282. DOI: 10.1111/j.1468-0033.1950.tb00111.x.

Christison, M. B. (1955). 'The Virginia Museum of Fine Arts' Artmobile Richmond, Virginia'. Museum 8 (2). DOI: 10.1111/j.1468-0033.1956.tb00283.x.

Contier, D. (2009). 'Relações entre ciência, tecnologia e sociedade em museus de ciências'. Dissertação (Mestrado em Educação). São Paulo, Brazil: Universidade de São Paulo.

Cors, R. (2013). MobiLLab Program Background Investigation: Directions for Program Improvement and Evaluation Research (Verschaffen eines Überblicks des mobiLLabs). St. Gallen, Switzerland: University of Teacher Education.

- (2016). 'Informal science learning: An investigation of how novelty and motivation affect interest development at a mobile laboratory'. Thèse de doctorat. Genève, Switzerland: Université de Genève.

Cors, R. and Robin, N. (2016). 'Evaluating informal science education: Identifying and measuring meaningful indicators of program effectiveness for a mobile laboratory program'. Journal of Finnish Universities of Applied Sciences (Special Issue: April).

Cortassa, C. (2016). 'In science communication, why does the idea of a public deficit always return? The eternal recurrence of the public deficit'. Public Understanding of Science 25 (4), pp. 447-459. DOI: 10.1177/0963662516629745. PMID: 27117772.

Costa, T. M. L., Norberto Rocha, J. and Poenaru, L. M. (2014). A formação à distância de mediadores do Museu Itinerante Ponto UFMG. Belo Horizonte, Brazil: Rede Informal de Museus e Centros Culturais de Belo Horizonte e Região Metropolitana.

Daifuku, H. (1963). 'Exhibitions in the Technically Underdeveloped Countries'. In: Museums and Monuments X. Temporary and travelling exhibitions. Dusseldorf, Germany: Unesco.

Daifuku, H. (1965). 'An experimental mobile museum for Tropical Africa'. Museum International 18 (3), pp. 126-129. DOI: 10.1111/j.1468-0033.1965.tb01581.x.

Disher, K. B. (1947). 'The Traveling Trailside Museum'. Explorer 92 (Autumn), pp. 1-4.

- (1950). 'Mobile Museum Units'. Fundamental Education III (4), pp. 21-25.

Ferreira, J. R., Bevilaqua, D. V., Damico, J. S., Fandi, J., Gomes, I., Soares, M. and Mano, S. (2012). ‘Perfil e opinião dos visitantes do Ciência Móvel — Vida e Saúde para todos'. Tempo Brasileiro 188, pp. 125-138. 
Floud, P. (1950). 'Le service de prêt du Victoria and Albert Museum'. Museum International (Edition Francaise) 3 (4), pp. 296-303.

DOI: $10.1111 / j .1755-5825.1950 . t b 00056 . x$.

Gaspar, A. (1993). 'Museus e centros de ciências - conceituação e proposta de um referencial teórico'. Tese de Doutorado. São Paulo, Brazil: Universidade de São Paulo.

Ghose, S. K. (1968). 'Mobile science exhibitions of the Birla Industrial and Technological Museum, Calcutta'. Museum International 21 (4), pp. 294-300. DOI: $10.1111 / j .1468-0033.1968 . t b 02188 . x$.

- (2015). 'Science on wheels: a retrospective'. Kolkata: NCSM. URL: http://ncsm. gov . in/?p=4921.

Ghose, S. (1986). 'Les musées des sciences sortent de leurs murs'. Museum International (Edition Francaise) 38 (2), pp. 100-106. DOI: $10.1111 / j .1755-5825.1986 . t b 01028 . x$.

Gille, A. (1954). ‘UNESCO's travelling science exhibitions'. Museum 7 (4), pp. 276-279.

Gonçalves, A. M. M. (2010). 'O uso de um recurso audiovisual no Projeto Ciência Móvel - Vida e Saúde para Todos: Avaliação do filme "O Mundo Macro e Micro do Mosquito Aedes aegypti - Para combatê-lo é preciso conhecê-lo"'. Monografia de Especialização. Rio de Janeiro, Brazil: Fundação Oswaldo Cruz.

Gonçalves, J. C. (2014). 'Estudo exploratório do perfil opinião dos docentes da Caravana da Ciência - Fundação CECIERJ'. Monografia de Especialização. Rio de Janeiro, Brazil: Fundação Oswaldo Cruz.

Gore, M. (2001). 'The Questacon Story'. In: Science Communication in Theory and Practice. Ed. by S. M. Stocklmayer, M. M. Gore and C. Bryant. Dordrecht, the Netherlands: Kluwer Academic Publishers. DOI: 10.1007/978-94-010-0620-0.

Grobman, A. B. (1958). 'Museum Extension through Traveling Museums'. Curator: The Museum Journal 1 (4), pp. 82-88. DOI: $10.1111 / j .2151-6952.1958 . t b 00381 . x$.

Hatt, R. T. (1950). 'The Temporary Exhibitions in the Science Museum'. Museum International 3 (4), pp. 313-316. DOI: 10.1111/j.1468-0033.1950.tb00117 . x.

Hine, A. and Medvecky, F. (2015). 'Unfinished Science in Museums: a push for critical science literacy'. JCOM 14 (02), A04. URL: https://jcom.sissa.it/archive/14/02/JCOM_1402_2015_A04.

Hudson, D. S. (1966). 'The Virginia Museum Artmobiles'. Art Journal 25 (3), p. 258. DOI: $10.2307 / 774986$.

Inacio, L. G. B. (2017). 'Indicadores de acessibilidade em museus e centros de ciências: aplicação na Caravana da Ciência'. Monografia de Especialização em Ensino de Ciências - Ênfase em Biologia e Química. Rio de Janeiro, Brazil: Instituto Federal do Rio de Janeiro (IFRJ).

Jones, A. L. and Stapleton, M. K. (2017). '1.2 million kids and counting-Mobile science laboratories drive student interest in STEM'. PLOS Biology 15 (5), e2001692. DOI: 10.1371/journal.pbio. 2001692.

Kotchetkov, V. P. (2010). 'Science and Technology Policy in Unesco: a historical overview'. In: History and Philosophy of Science and Technology - Volume II. Ed. by P. Lorenzano, H. Rheinberger, E. Ortiz and C. D. Galles. United Kingdom: EOLSS Publications.

Layton, D. (1995). UNESCO and the teaching of science and technology. Paris, France: Unesco.

Leher, R. (1999). 'Um novo senhor da educação? A política do Banco Mundial para a periferia do capitalismo'. Outubro 1 (3), pp. 19-30. 
Lorentz, S. (2009). 'Mobile Museums in Poland'. Museum International 3 (4), pp. 283-285. DOI: 10.1111/j.1468-0033.1950.tb00112.x.

Lourenço, M. F. (2017). 'Materiais educativos em museus e sua contribuição para a alfabetização científica'. Tese de Doutorado em Educação. São Paulo, Brazil: Universidade de São Paulo.

Maitra, R. (1997). 'The Growth of Science Museums in India'. Museum International 49 (1), pp. 49-53. DOI: 10.1111/1468-0033.00076.

Marandino, M. (2016). 'The expositive discourse as pedagogical discourse: studying recontextualization in the production of a science museum exhibition'. Cultural Studies of Science Education 11 (2), pp. 481-514. DOI: $10.1007 / \mathrm{s} 11422-014-9625-9$.

Massarani, L. and De Castro Moreira, I. (2016). 'Science communication in Brazil: A historical review and considerations about the current situation'. Anais da Academia Brasileira de Ciências 88 (3), pp. 1577-1595. DOI: $10.1590 / 0001-3765201620150338$.

Michalowski, K. (1950). 'Les Expositions Itinérantes dans les Musées de Pologne'. Museum International (Edition Francaise) 3 (4), pp. 275-282. DOI: $10.1111 / j .1755-5825.1950 . t b 00052 . x$.

Mingues, E. (2014). ‘O museu vai à praia: uma análise de uma ação educativa à luz da Alfabetização Científica'. Dissertação de Mestrado. São Paulo, Brazil: Universidade de São Paulo.

Moreira, I. and Massarani, L. (2002). 'Aspectos históricos da divulgação científica no Brasil'. In: Ciência e Público: caminhos da divulgação científica no Brasil. Ed. by L. Massarani, I. Moreira and F. Britto. Rio de Janeiro, Brazil: Casa da Ciência - Centro Cultural de Ciência e Tecnologia da UFRJ.

Moreira, I. C., Massarani, L. and Aranha, J. (2008). 'Roquette-Pinto e a divulgação científica'. In: Antropologia Brasiliana - Ciência e educação na obra de Edgar Roquette-Pinto. Ed. by N. T. Lima and D. M. Sá. Brazil: Editora UFMG / Editora Fiocruz.

Morley, G. (1950). ‘Introduction'. Museum 3 (4), pp. 264-266.

Mukhopadhyay, I. K. (2005). 'The science centre movement in India: a conspectus'. História, Ciências, Saúde-Manguinhos 12 (supplement), pp. 281-307. DOI: $10.1590 / \mathrm{s} 0104-59702005000400014$.

Navas, A. M. (2008). 'Concepções de popularização da ciência e da tecnologia no discurso poliìtico: impactos nos museus de ciências'. Dissertação de Mestrado. Saõ Paulo, Brazil: Universidade de São Paulo.

Norberto Rocha, J. (2015). 'Caravana da Ciência: sete anos de itinerância no Rio de Janeiro e muito mais'. In: Libros de Memorias do Congreso RedPop 2015. Colombia: RedPop, pp. 226-233.

- (2016). 'Museus e centros de ciências itinerantes: Análise das exposições e processos de alfabetização científica. Qualificação da tese'. Doutorado em Educação. São Paulo, Brazil: Universidade de São Paulo.

- (ND). 'Museus e centros de ciências itinerantes: análises das exposições e processos de alfabetização científica'. Trabalho não publicado (comunicação pessoal). Doutorado em Educação. São Paulo, Brazil: Universidade de São Paul.

Nunes, O. (2007). ‘Feira de Idéias'. In: Feiras de Reis: cem anos de divulgação científica no Brasil. Ed. by G. Kreinz, C. Pavan and C. M. Filho. São Paulo, Brazil: Publicações NJR. 
Oliveira, D. (2016). ‘Biodiversidade em políticas públicas de Ciência, Tecnologia e Inovação: caracterização e perspectivas na integração do fomento à divulgação e educação em ciências'. Tese de Doutorado em Educação em Ciências: Química da Vida e Saúde. Brazil: Universidade Federal do Rio Grande-Associação ampla FURG/UFRGS/UFSM.

Osborn, E. C. Museums and Monuments V. Manual of Travelling Exhibitions. Dusseldorf, Germany: Unesco.

Osborn, E. C. and Morley, G. (1963). 'Travelling Exhibitions'. In: Museums and Monuments X. Temporary and travelling exhibitions. Dusseldorf, Germany: Unesco.

Pereira, M. R. N. (2010). 'Entre Dimensões e funções educativas: A trajetória da

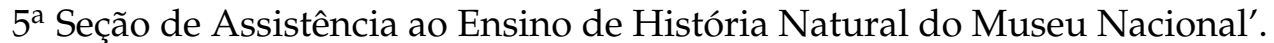
Dissertação (Mestrado em Museologia e Patrimônio). Rio de Janeiro, Brazil: Universidade Federal do Estado do Rio de Janeiro e Museu de Astronomia e Ciências Afins.

Perotti, R. T. (2005). 'José Hidashi e os naturalistas no "coração bárbaro" do Brasil'. Dissertação de Mestrado em Gestão do Patrimônio Cultural. Goiânia, Brazil: Universidade Católica de Goiás.

Petitjean, P., Zharov, V., Glaser, G., Richardson, J., De Padirac, B. and Archibald, G. (2006). Sixty Years of Science at UNESCO 1945-2005. Paris, France: Unesco.

Pinto, S. P. (2014). 'A construção do discurso da mediação humana em atividades itinerantes de divulgação da ciência'. Tese de Doutorado. Rio de Janeiro, Brazil: Universidade Federal do Rio de Janeiro.

Raw, I. (1970). An effort to improve science education in Brazil. (mimeo). São Paulo, Brazil: IBECC.

Rees, J. (2016). A Brief History of the Mobile Museum: What it is, what it was, and what it can be. Museum Studies Program Final Products. U.S.A.: University of Kansas.

Reiser, R. A. (2001). 'A history of instructional design and technology: Part I: A history of instructional media'. Educational Technology Research and Development 49 (1), pp. 53-64. DOI: $10.1007 /$ bf 02504506.

Rivière, G. H. (1960). 'Stage régional d'études de L'UNESCO sur le rôle éducatif des musées'. Etudes et documents d'éducation 38.

Saettler, P. (1968). A history of instructional technology. New York, U.S.A.: McGraw-Hill.

Schwenck, B. (2011). 'Ciência Móvel: a mediação informacional nas exposições de um museu itinerante'. Dissertação de Mestrado. Rio de Janeiro, Brazil: Universidade Federal do Rio de Janeiro.

Supplee, C. (1974). 'Museum on wheels'. Museum News (october), pp. 27-35.

Tavares, O. A. P. (2006). Notas biográficas. Ed. by MAST. Rio de Janeiro, Brazil: MAST.

Tojal, A. P. F. (2007). 'Políticas Públicas de Inclusão de Públicos Especiais em Museus'. Tese de Doutorado em Ciências da Informação. São Paulo, Brazil: Universidade de São Paulo.

- (2015). 'Política de acessibilidade comunicacional em museus: Para quê e para quem?' Museologia E Interdisciplinaridade IV (7).

Unesco (1950). Report of the Director-General on the Activities of the Organization from October 1949 to March 1950. Paris, France: Unesco.

- (1951). 'Unesco's main activities in the Western Hemisphere'. Memorandum presented to the First Meeting of the Inter-American Cultural Council. Paris, France: Unesco. 
Unesco (1954). Unesco presents 'Man measures the Universe' a travelling science exhibition. Paris, France: Unesco.

- (1958a). Report concerning the possibility of establishing international regulations on the most effective means of rendering museums accessible to everyone. Unesco General Conference, Tenth Session. Paris, France: Unesco.

- (1958b). Seminario regional de la Unesco sobre la función educativa de los museos. Paris, France: Unesco.

- (1958c). Terms of Consignment to member states of the travelling science exhibition 'The Earth as a Planet'. Paris, France: Unesco.

- (1959a). Unesco Travelling Science Exhibition on Automation. Exhibition documents. Committee of Scientific Advisers for the Travelling Science Exhibition on Automation. Paris, France: Unesco.

- (1959b). Unesco Travelling Science Exhibition 'The Galapagos Islands: evolution's show-window'. Exhibition documents. Paris, France: Unesco.

- (1963). Museums and Monuments X. Temporary and travelling exhibitions. Dusseldorf, Germany: Unesco.

Valente, M. E. A. (2008). 'Museus de Ciências e Tecnologia no Brasil: uma história da museologia entre as décadas de 1950-1970'. Tese de Doutorado — Programa de Pós-graduação em Ensino e História de Ciências da Terra. Campinas, Brazil: Universidade Estadual de Campinas.

Vitae, F. (2006). Relatório final 1985 a 2006. Relatório anual 2005. São Paulo, Brazil: Vitae.

Ševčuk, V. A. (1966). 'Travelling exhibitions and mobile museums'. Museum International 19 (3), pp. 156-159. DOI: 10.1111/j.1468-0033.1966.tb01617.x.

Xavier, D. W. (2012). 'Museus em Movimento. Uma reflexão acerca de experiências museológicas itinerantes no marco da Nova Museologia'. Dissertação de Mestrado. Lisboa, Portugal: Universidade Lusófona de Humanidades e Tecnologias.

Zucker, B. F. (1983). 'A Survey of Outreach and Loan Programs Offered by Museums'. Curator: The Museum Journal 26 (2), pp. 155-174. DOI: $10.1111 / j .2151-6952.1983 . t b 00603 . x$.

- (1989). 'A Traveling Museum and Where It Went'. Curator: The Museum Journal 32 (3), pp. 199-211. DOI: 10.1111/j.2151-6952.1989.tb00720.x.

Authors

Jessica Norberto Rocha is a Ph.D. student at the University of São Paulo (USP) and works as a manager of the mobile science centre Caravan of Science at CECIERJ Foundation (Brazil). E-mail: jessicanorberto@yahoo.com.br.

Martha Marandino is a professor at the University of São Paulo (USP) and a researcher in science education, $S \& T$ studies and museum education.

E-mail: marmaran@usp.br.

How to cite

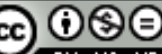

Norberto Rocha, J. and Marandino, M. (2017). 'Mobile science museums and centres and their history in the public communication of science'.

JCOM 16 (03), A04. 